\title{
Expanding the Scope of the Cleavable $N$-(methoxy)oxazolidine Linker for the Synthesis of Oligonucleotide Conjugates
}

\author{
Aapo Aho, Antti Äärelä, Heidi Korhonen and Pasi Virta * \\ Department of Chemistry, University of Turku, 20014 Turku, Finland; aamaah@utu.fi (A.A.); \\ ankaaar@utu.fi (A.Ä.); hejoli@utu.fi (H.K.) \\ * Correspondence: pamavi@utu.fi; Tel.: +358-503-285-719
}

Citation: Aho, A.; Äärelä, A.; Korhonen, H.; Virta, P. Expanding the Scope of the Cleavable $\mathrm{N}$-(methoxy)oxazolidine Linker for the Synthesis of Oligonucleotide Conjugates. Molecules 2021, 26, 490. https://doi.org/10.3390/ molecules 26020490

Academic Editor: Nicola Borbone Received: 22 December 2020

Accepted: 11 January 2021

Published: 18 January 2021

Publisher's Note: MDPI stays neutral with regard to jurisdictional claims in published maps and institutional affiliations.

Copyright: (c) 2021 by the authors. Licensee MDPI, Basel, Switzerland. This article is an open access article distributed under the terms and conditions of the Creative Commons Attribution (CC BY) license (https:/ / creativecommons.org/licenses/by/ $4.0 /)$.

\begin{abstract}
Oligonucleotides modified by a 2'-deoxy-2'-(N-methoxyamino) ribonucleotide react readily with aldehydes in slightly acidic conditions to yield the corresponding $N$-(methoxy)oxazolidinelinked oligonucleotide-conjugates. The reaction is reversible and dynamic in slightly acidic conditions, while the products are virtually stable above $\mathrm{pH}$ 7, where the reaction is in a "switched off-state". Small molecular examinations have demonstrated that aldehyde constituents affect the cleavage rate of the $N$-(methoxy)oxazolidine-linkage. This can be utilized to adjust the stability of this $\mathrm{pH}$-responsive cleavable linker for drug delivery applications. In the present study, Fmoc- $\beta$-Ala-H was immobilized to a serine-modified ChemMatrix resin and used for the automated assembly of two peptidealdehydes and one aldehyde-modified peptide nucleic acid (PNA). In addition, a triantennary $N$-acetyl-D-galactosamine-cluster with a $\beta$-Ala-H unit has been synthesized. These aldehydes were conjugated via $\mathrm{N}$-(methoxy)oxazolidine-linkage to therapeutically relevant oligonucleotide phosphorothioates and one DNA-aptamer in $19-47 \%$ isolated yields. The cleavage rates of the conjugates were studied in slightly acidic conditions. In addition to the diverse set of conjugates synthesized, these experiments and a comparison to published data demonstrate that the simple conversion of Gly-H to $\beta$-Ala-H residue resulted in a faster cleavage of the $N$-(methoxy)oxazolidine-linker at $\mathrm{pH} 5$, being comparable $\left(\mathrm{T}_{0.5}\right.$ ca $\left.7 \mathrm{~h}\right)$ to hydrazone-based structures.
\end{abstract}

Keywords: oligonucleotide conjugates; cleavable linker; $\mathrm{N}$-(methoxy)oxazolidine

\section{Introduction}

Oligonucleotide (ON) therapeutics, such as antisense oligonucleotides (ASO) and small interfering RNAs (siRNAs), can be applied for the modulation of gene expression in a wide range of disorders [1-9]. Despite the great potential of ONs as drugs, they suffer from poor pharmacokinetic properties [10]. Backbone modifications such as phosphorothioate and $2^{\prime}-O$-substitutions improve the stability and increase the plasma circulation time of Ons $[10,11]$, but cell/tissue-specific extrahepatic delivery has remained a challenge [8,12]. For targeted delivery, antibodies [13-15], aptamers [16,17], nanoparticles [18], extracellular vesicles [19], carbohydrates [20-22], cholesterol [23,24] $\mathrm{m}$ and other small molecules [25-27] have been utilized. However, almost without exception these strategies lead to the endosomal entrapment of ONs $[15,18,28]$. Endosomal escape may be facilitated by other structural modifications or conjugate groups [29-31], which may make the overall synthesis complex. In the synthesis of these biomolecular hybrids, in which even the bis-conjugation of ONs is needed, orthogonal ligation chemistries play a central role. It is beneficial if the conjugation itself creates a linker that is cleavable [32-34]. The linker should also provide efficient conjugation, be stable in physiological conditions, and release the therapeutic ON cargo in appropriate intracellular compartments. Examples of such linkers are hydrazones $[35,36]$, which are cleaved in slightly acidic conditions perceived to that in endosomes and lysosomes, and disulfides $[14,16]$, which are cleaved in a mildly reducible environment in cytosol. Hence, the former linker chemistry may be suitable for 
the conjugation of cell/tissue targeting vehicles, whereas the latter may be suitable for the conjugation of endosomal escaping moieties. Expanding the chemistry of reversible linkers is important to find efficient orthogonal conjugation strategies and the targeted release of ON therapeutics in biological mediums.

Recently, the reversible formation of $\mathrm{N}$-(methoxy)oxazolidine (Figure 1) was employed in conjugation between 2'-deoxy-2'-( $\mathrm{N}$-methoxyamino)uridine ( $\mathbf{U}^{\mathrm{NOMe}}$, Scheme 1a)-modified ONs and Gly-H-modified peptide aldehydes [37]. The $\mathbf{U}^{\mathrm{NOMe}}$-ONs and peptide aldehydes were both synthesized by automated assembly using appropriately modified solid supports. After cleavage, deprotection, and purification, the $\mathbf{U}^{\mathrm{NOMe}}-\mathrm{ONs}$ and the peptide aldehydes were mixed in slightly acidic conditions to yield conjugates in reasonable yields. The conjugates were stable during RP HPLC purification and lyophilization, but showed an aciddependent hydrolytic cleavage. ONs were released from Gly-H-modified peptide aldehydes with a half-life $\left(\mathrm{t}_{0.5}\right)$ of $5.8,42$, and $220 \mathrm{~h}$ at $\mathrm{pH} 4,5$, and 6, respectively $\left(37^{\circ} \mathrm{C}\right)$ (cf. Table 1 entries 1-3), and only $11 \%$ was released after two weeks of incubation at $\mathrm{pH} 7\left(37^{\circ} \mathrm{C}\right)$. It was additionally shown by small molecular models that the rate of the $N$-(methoxy)oxazolidine hydrolysis could be adjusted using structurally different aldehydes.<smiles>[R]C1OC2C(CO)OC1OC([R])N2n1ccc(=O)[nH]c1=O</smiles>

Figure 1. Formation of $N$-(methoxy)oxazolidines between $2^{\prime}$-deoxy-2'-(N-methoxyamino) uridine and small molecule aldehydes $(\mathrm{R}=\mathrm{cf}$. Table 2$)$.

A)
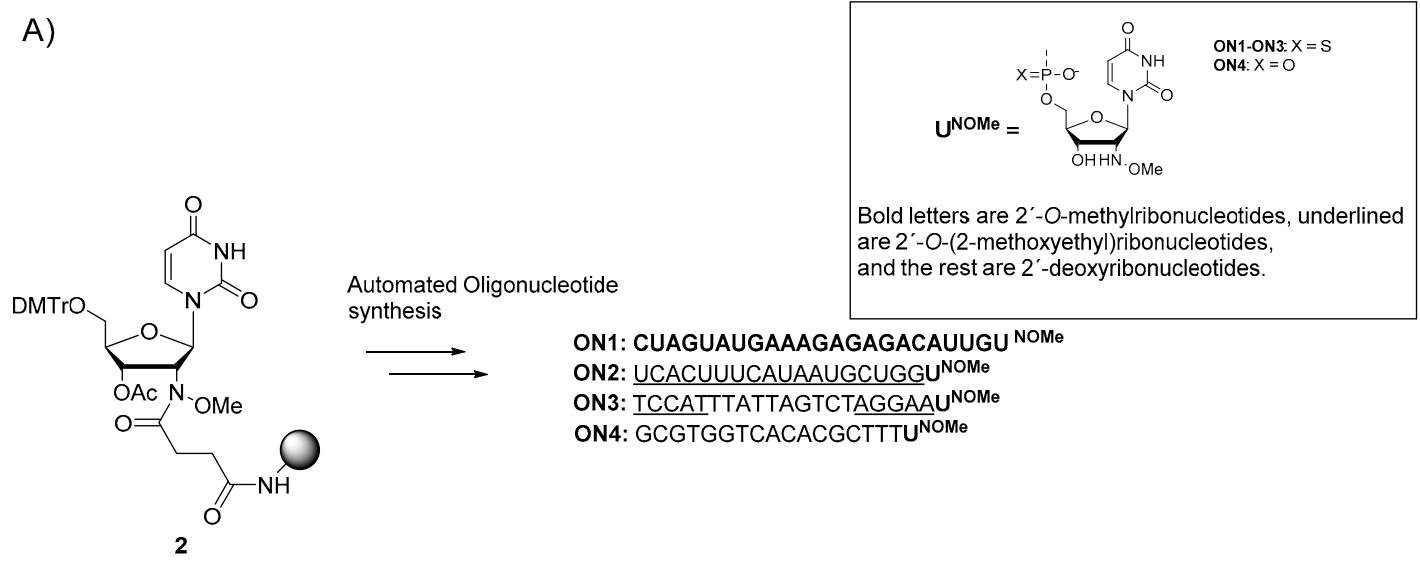

ON1: CUAGUAUGAAAGAGAGACAUUGU NOMe

ON2: UCACUUUCAUAAUGCUGGUNOMe

ON3: TCCATTTATTAGTCTAGGAAUNOME

ON4: GCGTGGTCACACGCTTTUNOME

B)

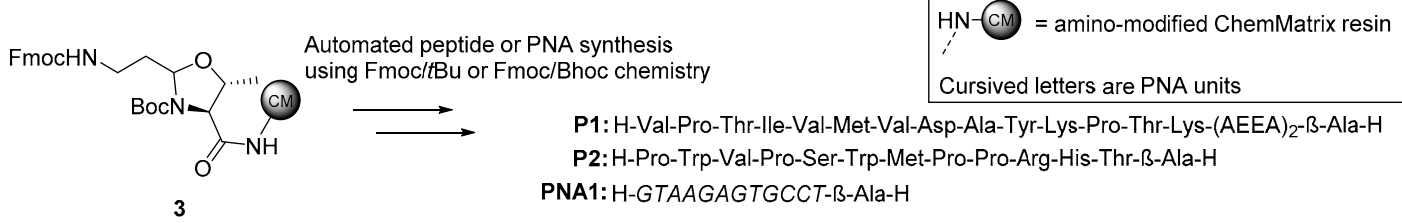

Scheme 1. (A) Automated synthesis of UNOMe -elongated oligonucleotides (ON1, ON2, ON3, and ON4) using UNOMe solid support. (B) Automated synthesis of $\beta$-Ala-H-modified peptides (P1 and P2) and PNA (PNA1) using Fmoc- $\beta$-Ala-H bound on an amino-modified ChemMatrix resin via $N$-Boc-oxazolidine. 
Table 1. Hydrolysis rates of the $\mathbf{U}^{\text {NOMe }}$ conjugates at $37^{\circ} \mathrm{C}$.

\begin{tabular}{ccccc}
\hline Entry & Conjugate $^{\mathbf{a}}$ & $\mathbf{p H}^{\mathbf{b}}$ & $\mathbf{t}_{\mathbf{0 . 5}} \mathbf{( h )}$ & ON Released at Equilibrium (\%) $^{\mathbf{b}}$ \\
\hline $\mathbf{1}^{\mathbf{c}}$ & $\mathbf{C 1}^{*}$ & 4 & $5.80 \pm 0.52$ & $95.2 \pm 2.1$ \\
$\mathbf{2}^{\mathbf{c}}$ & $\mathbf{C 1}^{*}$ & 5 & $41.7 \pm 2.3$ & $95.8 \pm 1.6$ \\
$\mathbf{3}^{\mathbf{c}}$ & $\mathbf{C 1}^{*}$ & 6 & $222 \pm 20$ & quant. \\
$\mathbf{4}$ & $\mathbf{C} \mathbf{1}$ & 4 & $1.53 \pm 0.25$ & $91.5 \pm 5.1$ \\
$\mathbf{5}$ & $\mathbf{C} \mathbf{1}$ & 5 & $7.17 \pm 0.77$ & $89.7 \pm 2.9$ \\
$\mathbf{6}$ & $\mathbf{C} \mathbf{1}$ & 6 & $37.3 \pm 3.3$ & $95.7 \pm 3.4$ \\
$\mathbf{7}$ & $\mathbf{C} 2$ & 5 & $4.41 \pm 0.17$ & $59.2 \pm 0.6$ \\
$\mathbf{8}$ & $\mathbf{C} 3$ & 5 & $10.2 \pm 0.81$ & $94.8 \pm 2.4$ \\
$\mathbf{9}$ & $\mathbf{C} 4$ & 5 & $7.40 \pm 1.03$ & $63.9 \pm 2.5$ \\
\hline
\end{tabular}

a $10 \mu \mathrm{M}$ initial concentration. ${ }^{\mathrm{b}} 100 \mathrm{mM} \mathrm{NaOAc} / \mathrm{AcOH} .{ }^{\mathrm{c}}$ Previously published data [36].

In this study, the scope of the $N$-(methoxy)oxazolidine ligation was expanded by the synthesis of a more diverse set of conjugates. $\mathbf{U}^{\mathrm{NOMe}}$-extended ONs, consisting of three therapeutically relevant ONs, ISE-AR-V7 [38], Nusinersen [39], IONIS-DGAT2Rx [40,41], and one DNA-aptamer, TfRA3 [42], were synthesized and conjugated to four different $\beta$-Ala-H-containing biomolecules: SpyTag [43], D-retro inverso THR [44-46], an antisense PNA [47], and a trivalent $N$-acetyl galactosamine (GalNAc) cluster (cf. further description of these biomolecules below). The ligation products could be obtained in $19-47 \%$ isolated

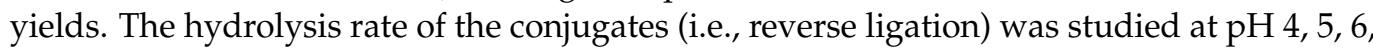
and 7.4. The $N$-(methoxy)oxazolidine linker, bound to the $\beta$-Ala-H residue, clearly cleaved faster in acidic conditions ( $\mathrm{pH} 4-6$ ) than the previously studied Gly-H-based conjugates [37]. The cleavage was comparable to most hydrazone linkers, and the conjugates maintained their hydrolytic stability in physiological conditions ( $\mathrm{pH} 7.4)$.

\section{Results}

\subsection{Small Molecular Model Study}

Prior to real conjugation experiments (described below), the $N$-(methoxy)oxazolidine formation with a $\beta$-Ala-H residue was studied using small-molecule models. $2^{\prime}$-deoxy- $2^{\prime}$ (N-methoxyamino)uridine $(\mathbf{1}, 5 \mathrm{mM})$ and $N$-Bz- $\beta$-Ala-H $(5 \mathrm{mM})$ were mixed in buffered aqueous solution $(\mathrm{pH} 4)$ at room temperature and the progress of the reaction was followed by RP HPLC. As expected, two $N$-(methoxy)oxazolidine ligation products (R/S isomers) were formed (cf. RP HPLC profile of the reaction and characterization of the products in Supplementary Materials). The reaction stalled at equilibrium $\left(K=2.82 \pm 0.43 \times 10^{3} \mathrm{~L} \mathrm{~mol}^{-1}\right)$, yielding a $75 \%$ conversion of $\mathbf{1}$ to the ligation products. The hydrolysis rate of the obtained $\mathrm{N}$-(methoxy)oxazolidine was determined at $\mathrm{pH} 4,5$, and 6 by following the degradation of the major ligation product. As expected, the hydrolysis rate was $\mathrm{pH}$-dependent, with half-lives of 5.3, 29, and $310 \mathrm{~h}$ at $\mathrm{pH} \mathrm{4,5}$, and 6, respectively, being ca. three-fold faster than the hydrolysis of $\mathrm{N}-\mathrm{Bz}-\mathrm{Gly}-\mathrm{H}$ ligation product (Figure 1 and Table 2). Despite the modest rate enhancement of the hydrolysis, this model reaction was well-behaving and promising, considering the conjugation of ONs with $\beta$-Ala-H-containing biomolecules.

Table 2. Formation and decay of $N$-(methoxy)oxazolidines between $2^{\prime}$-deoxy-2'-( $N$-methoxyamino) uridine and small molecular aldehydes.

\begin{tabular}{|c|c|c|c|c|c|}
\hline Entry & $\mathbf{R}^{\mathbf{b}}$ & $\mathrm{pH}$ & $t_{0.5} \operatorname{Decay}(h)^{c}$ & $\begin{array}{l}\text { Equilibrium Constant } K \\
\qquad\left(1 \mathrm{~mol}^{-1}\right)^{\mathrm{c}}\end{array}$ & $\begin{array}{l}\text { Equilibrium Yield } \\
\qquad(\%)^{d}\end{array}$ \\
\hline $1^{a}$ & $\mathrm{BzNHCH}_{2}$ & 4 & $16.1 \pm 0.7$ & $4958 \pm 50$ & 82 \\
\hline $2^{a}$ & “ & 5 & $75.5 \pm 16.3$ & & \\
\hline $3^{a}$ & “ & 6 & $\mathrm{n} / \mathrm{a}$ & & \\
\hline 4 & $\mathrm{BzNHCH}_{2} \mathrm{CH}_{2}$ & 4 & $5.28 \pm 0.58$ & $2398 \pm 425$ & 75 \\
\hline 5 & " & 5 & $28.5 \pm 2.2$ & & \\
\hline 6 & " & 6 & $310 \pm 34$ & & \\
\hline
\end{tabular}

a Previously published data [37]. ${ }^{\mathrm{b}} \mathrm{Cf}$. $\mathrm{R}$ in Figure $1 .{ }^{\mathrm{c}}$ According to pseudo first-order rate law. ${ }^{\mathrm{d}}$ Acquired by mixing $1(5 \mathrm{mM})$ and aldehyde $(5 \mathrm{mM})$ at $\mathrm{pH} 4$. 


\subsection{Synthesis of 2'-deoxy'-2'-(N-methoxyamino)uridine-Modified Oligonucleotides}

Four oligonucleotides elongated by $\mathrm{U}^{\mathrm{NOMe}}$ (AON-ISE-AR-V7-UNOMe (ON1), Nusinersen$\mathrm{U}^{\mathrm{NOMe}}(\mathrm{ON} 2)$, IONIS-DGAT2 $\mathrm{Rx}-\mathrm{U}^{\mathrm{NOMe}}(\mathrm{ON} 3)$, and TfRA3-UNOMe $(\mathrm{ON} 4)$ (Scheme 1a) were next synthesized using previously prepared solid support 2 [37], commercial phosphoramidite building blocks, and automated chain assembly. AON-ISE-AR-V7 suppresses prostate tumor cell survival by the inhibition of androgen receptor variant 7 mRNA synthesis [38], Nusinersen is an approved drug used for treating spinal muscular athropy [39], and IONIS-DGAT2 ${ }_{\mathrm{RX}}$ ASO reduces DGAT2 enzyme production and is a potential treatment for nonalcoholic steatohepatitis [40,41]. TfRA3 is a transferring receptor-binding aptamer [41] that can act as a delivery vehicle to traverse the blood brain barrier (BBB) (i.e., the role of this $\mathrm{ON}$ in the cargo-delivery vehicle construct $\mathbf{C} 4$ is inverse compared to that of conjugates $\mathbf{C 1}-\mathbf{C} 3$, cf below). After chain elongation, cleavage with concentrated aqueous ammonia followed by RP HPLC purification gave the desired oligonucleotides in $29-40 \%$ yields (cf. supporting information).

\subsection{Synthesis of $\beta$-Ala-H-Modified Biomolecules}

Two peptide aldehydes and one PNA aldehyde were synthesized by following a published protocol $[48,49]$. Fmoc- $\beta$-Ala-H was bound to an amino-modified ChemMatrix resin via $N$-(Boc)oxazolidine to obtain solid support 3. On this support, SpyTag-(AEEA) $2-\beta$-Ala$\mathrm{H}(\mathbf{P 1})$, retro inverso THR- $\beta$-Ala-H (P2), and GluR3 antisense PNA- $\beta$-Ala-H (PNA1) were synthesized using automated Fmoc-chemistry (Scheme 1b). SpyTag peptide binds through irreversible isopeptide bond to a SpyCatcher protein domain [43]. This autocatalytic process has been utilized, e.g., for the preparation of antibody-ON-conjugates [50], but immunogenicity issues should be resolved prior to drug delivery applications. THR and its peptidase-resistant retro inverso version [44] binds to the transferrin receptor, and it has been applied to deliver RNA nanoparticles through the blood brain barrier [45,46]. GluR3 antisense PNA has been shown to reduce the glutamate excitotoxicity associated with amyotrophic lateral sclerosis (ALS) by reducing GluR3 protein expression [47]. After chain elongation, the peptides/PNA were cleaved from the resin using a TFA cocktail (cf. supporting information for more details); precipitated in cold ether; and dissolved in aq. $0.01 \%$ TFA to yield P1, P2, and PNA1, which were purified by RP HPLC (cf. supporting information).

One $\beta$-Ala-H-containing trivalent GalNAc cluster, with a good potential for liver targeting via asialoglycoprotein receptor [51], was additionally synthesized starting from branching unit 4 [52] consisting of three alkynyl and one aromatic aldehyde group (Scheme 2b). First, the aldehyde moiety was oxidized by Jones' condition using $\mathrm{Cr}_{3} \mathrm{O}$. The resulting carboxylic acid (5) was coupled to the diethoxy acetal of $\beta$-Ala-H using BOP/DIPEA activation to yield an amide (6). Then, the alkynyl groups of the core were coupled with (3-azidopropyl)-2acetamido-3,4,6-tri-O-acetyl-2-deoxy- $\beta$-D-galactopyranoside using $\mathrm{Cu}(\mathrm{I})$ catalyzed 1,3-dipolar cycloaddition (i.e., click reaction). Finally, the acetal protection of 7 was removed by aq $0.01 \%$ TFA to expose the $\beta$-Ala-H functionality. The final product 8 was prepared in an $18 \%$ yield after four steps. It may be worth mentioning that in our previous study aryl aldehydes (cf. 4) reacted only barely with 1 , and the $\beta$-Ala-H-extension (cf. 8 ) is crucial to gain an efficient conjugation.

\subsection{Synthesis of Oligonucleotide Conjugates C1-C4 Using N-(methoxy)oxazolidine Ligation}

The rationale of the synthesized conjugates $\mathrm{C} 1-\mathrm{C} 4$ below is based on the therapeutic relevance of the ASOs (cf. above) and the reported delivery potential of the corresponding conjugate groups to target tissues: $\mathbf{P} 2$ and $\mathbf{O N} 4$ could potentially enhance the CNS targeting of ON2 and PNA1 (i.e., C2 and C4) and increase their potential as intravenously administrated drugs. However, nanoparticle-based delivery systems may be additionally needed in this approach. The GalNac cluster 8 could increase the liver targeting of ON3 (C3). P1 can readily be extended to an antibody construct specific to prostate membrane antigen (PMSA) and, in this way, improve the targeting of ON1 (C1). The $\mathbf{U}^{\mathrm{NOMe}}$ oligonucleotides ON1, ON2, ON3, and ON4 were mixed with an excess of the corresponding $\beta$-Ala-H conjugate groups P1, P2, PNA1, and 8 (Scheme 2a) and incubated in AcOH/DMSO (1:3, 
$v / v$ ), $2 \mathrm{M} \mathrm{LiCl}$ at $55^{\circ} \mathrm{C}$ (reaction specific parameters in Table 3). After $1 \mathrm{~h}$ of incubation, the reaction mixtures were neutralized using dilute aq. $\mathrm{NaOH}$ and subjected as such to RP HPLC. As seen in the RP HPLC profiles of the crude product mixtures (Figure 2), a good conversion of the products was obtained with a moderate excess of the aldehyde constituents (P1, P2, PNA1, and 8, 2-8 equiv.). The product fractions were lyophilized to give the conjugates $\mathbf{C} 1, \mathbf{C} 2, \mathbf{C} 3^{\mathbf{A c}}$, and $\mathbf{C} 4$ in $19-47 \%$ yields (Table 3 ). Conjugate $\mathbf{C} 3^{\mathrm{Ac}}$ was deacetylated by soaking the conjugate in concentrated aq. ammonia ( $3 \mathrm{~h} \mathrm{at} \mathrm{rt)}$, and, without further purification, lyophilized to give C3.

A)

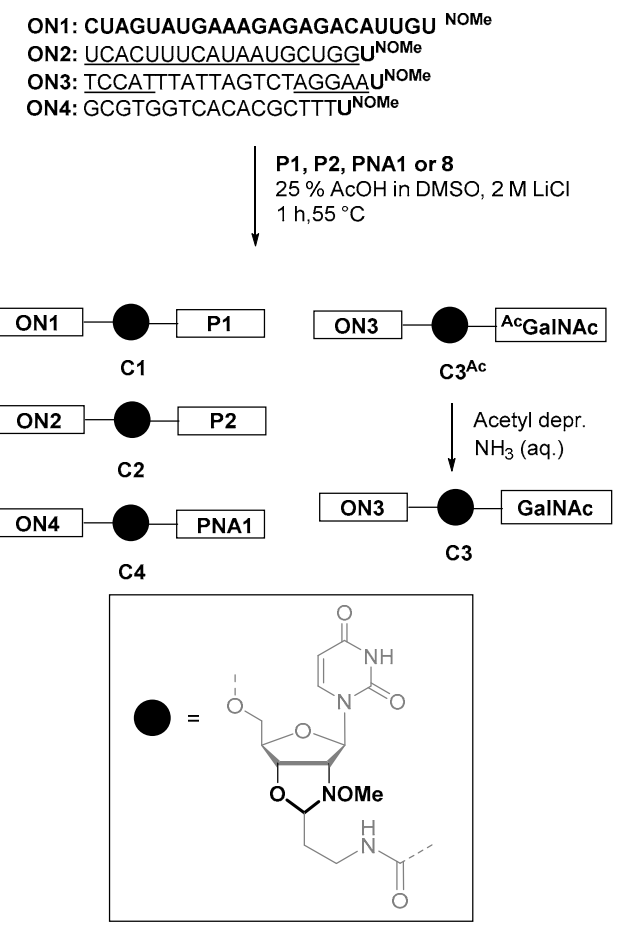

B)

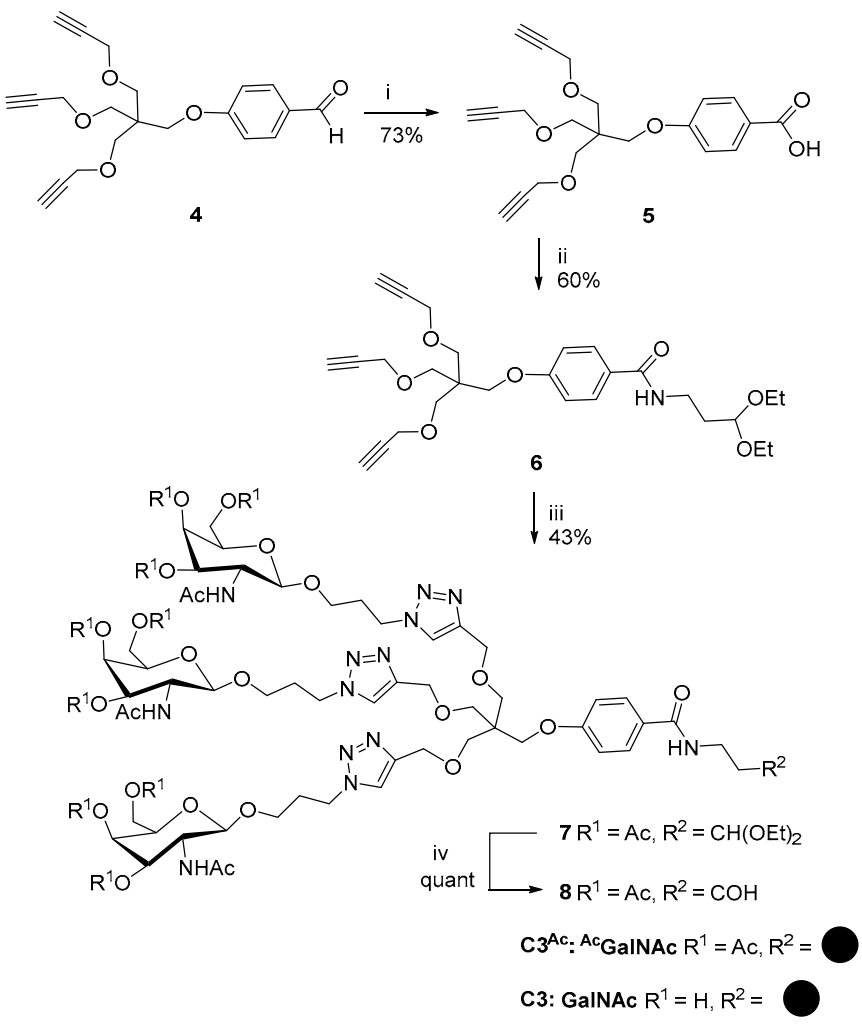

Scheme 2. (A) Synthesis of the conjugates C1, C2, C3, and C4. (B) Synthesis of the trivalent GalNAc conjugate group 8. Reaction conditions: (i) 3 equiv. Jones reagent, $\mathrm{MeCN}, 1 \mathrm{~h}$ at rt; (ii) 1.1 equiv. 3-amino-1,1-diethoxypropane, 2.5 equiv. $\mathrm{N}, \mathrm{N}$ diisopropyl ethylamine (DIPEA) 1.1 equiv BOP, DMF, on at rt; (iii) 5 equiv. (3-azidopropyl) 2-acetamido-3,4,6-tri-O-acetyl-2deoxy- $\beta$-D-galactopyranoside, catalytic $\mathrm{Cu}(\mathrm{I}) \mathrm{I}, \mathrm{DMF} /$ dioxane $/ \mathrm{H}_{2} \mathrm{O}(3: 3: 1, v / v / v)$, overnight at $40{ }^{\circ} \mathrm{C}$; (iv) aq. $0.01 \%$ TFA, $20 \mathrm{~min}$ at $55^{\circ} \mathrm{C}$.

Table 3. Data of the N-(methoxy)oxazolidine ligation to obtain conjugates C1-C4.

\begin{tabular}{cccccc}
\hline Conjugate & Aldehyde & $\begin{array}{c}\text { Aldehyde } \\
\text { Excess } \\
\text { (Equiv) }\end{array}$ & $\begin{array}{c}\text { Isolated } \\
\text { Yield d }\end{array}$ & $\begin{array}{c}\text { Observed } \\
\text { Molecular } \\
\text { Mass }\end{array}$ & $\begin{array}{c}\text { Calculated } \\
\text { Molecular } \\
\text { Mass }\end{array}$ \\
\hline C1 & P1 & 8 & $25 \%$ & $9999.4^{\mathrm{a}}$ & 9999.8 \\
C2 & P2 & 8 & $19 \%$ & $9006.2^{\mathrm{b}}$ & 9006.3 \\
C3 & $\mathbf{8}$ & 5 & $47^{\mathrm{a}}$ & $8851.1^{\mathrm{c}}$ & 8852.7 \\
C4 & PNA1 & 2 & $43^{\mathrm{c}}$ & $8860.4^{\mathrm{c}}$ & 8859.8 \\
\hline
\end{tabular}

Observed molecular masses were calculated from the most intensive isotope at $\left.{ }^{\mathrm{a}}[(\mathrm{M}-10 \mathrm{H}) / 10)\right]^{10}, \mathrm{~b}[(\mathrm{M}-6 \mathrm{H}) / 6]^{6-}$ and ${ }^{c}[(\mathrm{M}-4 \mathrm{H}) / 4]^{4-}$. $\mathrm{d}$ Yields were determined from the UV absorbance at $260 \mathrm{~nm}$ using the molar absorptivity of the corresponding nucleobases. 

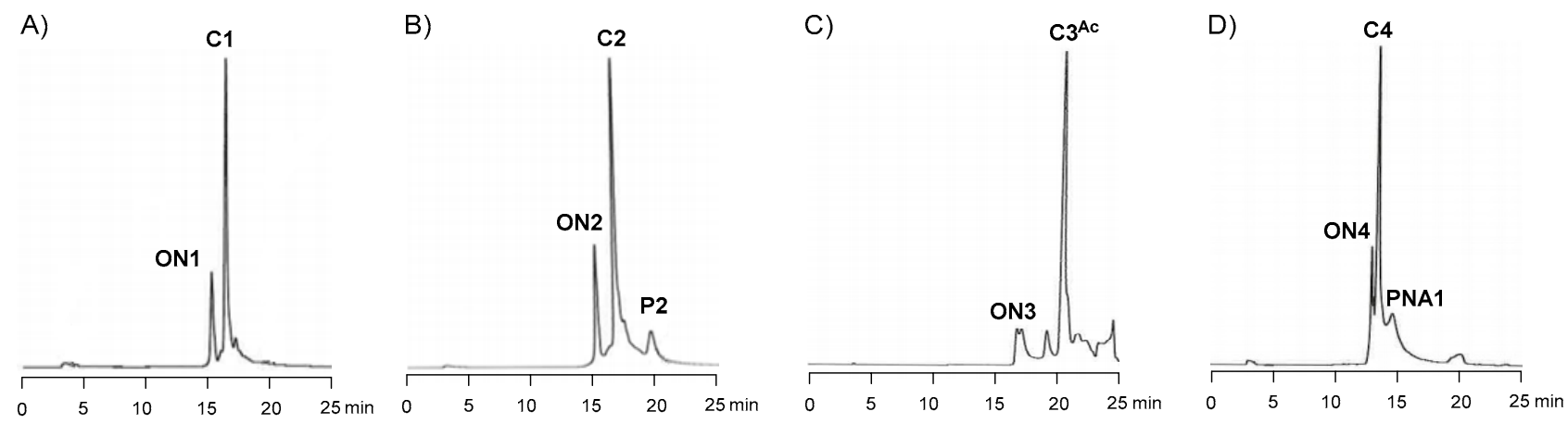

Figure 2. RP HPLC $(\mathrm{C} 18,250 \times 4.6 \mathrm{~mm}, 5 \mu \mathrm{m})$ profiles of $N$-methoxyoxazolidine conjugation crude product mixtures. A linear gradient of MeCN over aq. triethylammonium acetate (TEAA) buffer (pH 7) and a detection wavelength of $260 \mathrm{~nm}$ were employed. (A) Conjugate C1, 0-70\% MeCN in $25 \mathrm{~min}$; (B) Conjugate C2, 0-70\% MeCN in $25 \mathrm{~min}$; (C) $\mathbf{C 3}^{\mathrm{Ac}}, 0-60 \%$ $\mathrm{MeCN}$ in $25 \mathrm{~min}$; (D) C4, 0-70\% MeCN in $25 \mathrm{~min}$.

\subsection{Hydrolysis of the Ligations Products}

The hydrolysis rates of the conjugates (C1-C4) were studied by incubating them $(10 \mu \mathrm{M})$ in aq. buffers at $37^{\circ} \mathrm{C}$ and monitoring the release of the ONs by RP HPLC (Figures 3 and 4, Table 1). As predicted by the small-molecule models, ON1 released from $\beta$-Ala-H-derived conjugate $\mathbf{C 1}$ 5-6 times faster (at pH 5, $\mathrm{t}_{0.5}=7.17 \pm 0.77 \mathrm{~h}$ ) than from Gly-H-derived conjugate $\mathbf{C 1}^{*}$ (at pH 5, $\mathrm{t}_{0.5}=41.7 \pm 2.3$ ). Indeed, as illustrated in Figure 3, $\mathbf{C 1}$ requires approximately one $\mathrm{pH}$ unit less acidic environment than $\mathbf{C 1}^{*}$ to reach the same rate of hydrolysis in the range of $\mathrm{pH} 4-6$. Similarly, at $\mathrm{pH} 5$ conjugates $\mathbf{C 2}$, C3, and $\mathbf{C 4}$ were all hydrolyzed within $\mathrm{t}_{0.5}$ of $4.0-11.1 \mathrm{~h}$ (entries $7,8,9$ in Table 1). Interestingly, there was variation in the hydrolysis rates and also in the equilibrium yields. The reaction is most likely affected by the macromolecular interactions (e.g., by electrostatic interactions between the ONs and positively charged peptides), and not only by the closest environment of the reaction center. All the conjugates were virtually stable at $\mathrm{pH} 7.4$ after three days of incubation (Figure 4).
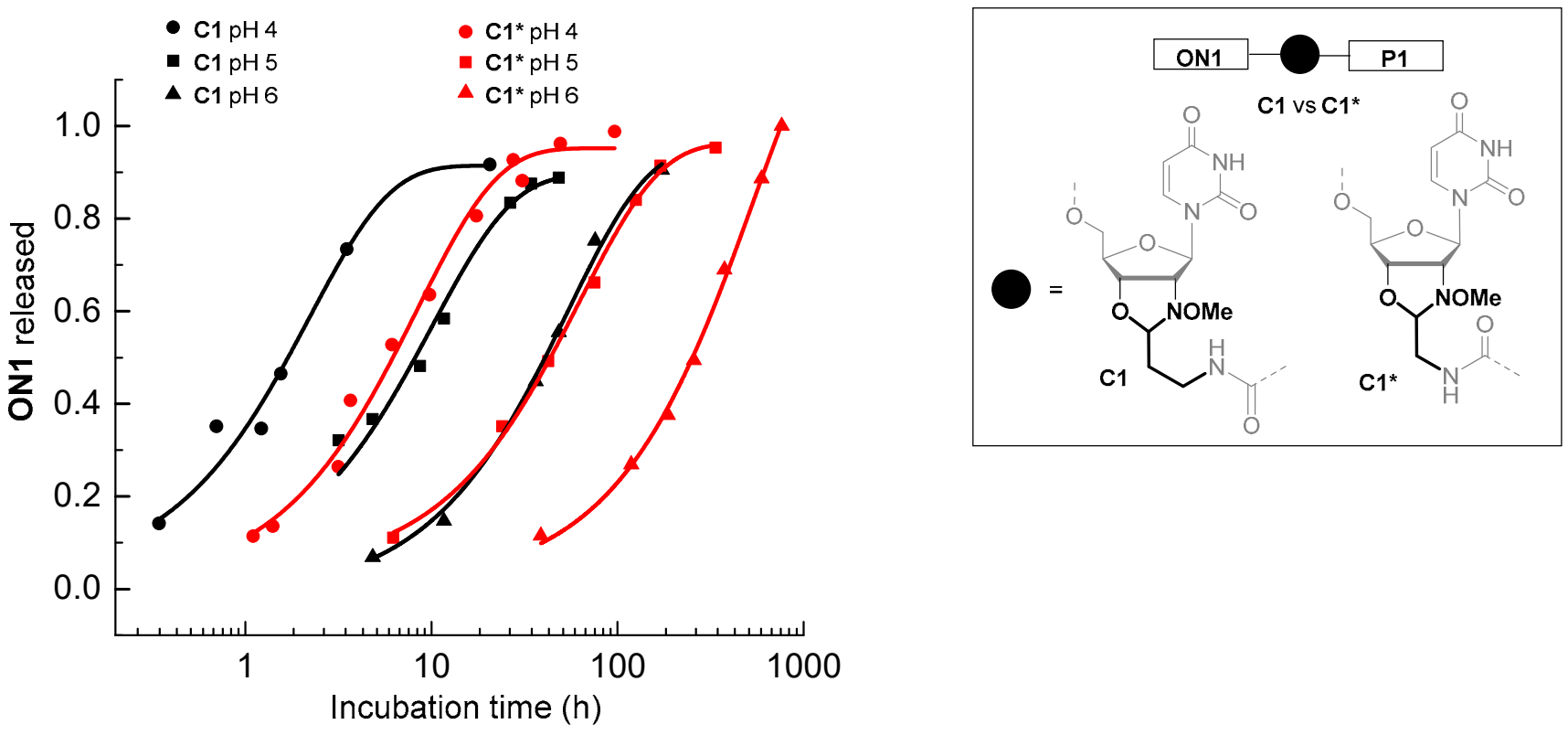

Figure 3. Comparison of the structures and hydrolysis rates of the analogous $\mathbf{C} 1$ and $\mathbf{C} \mathbf{1}^{*}$. 

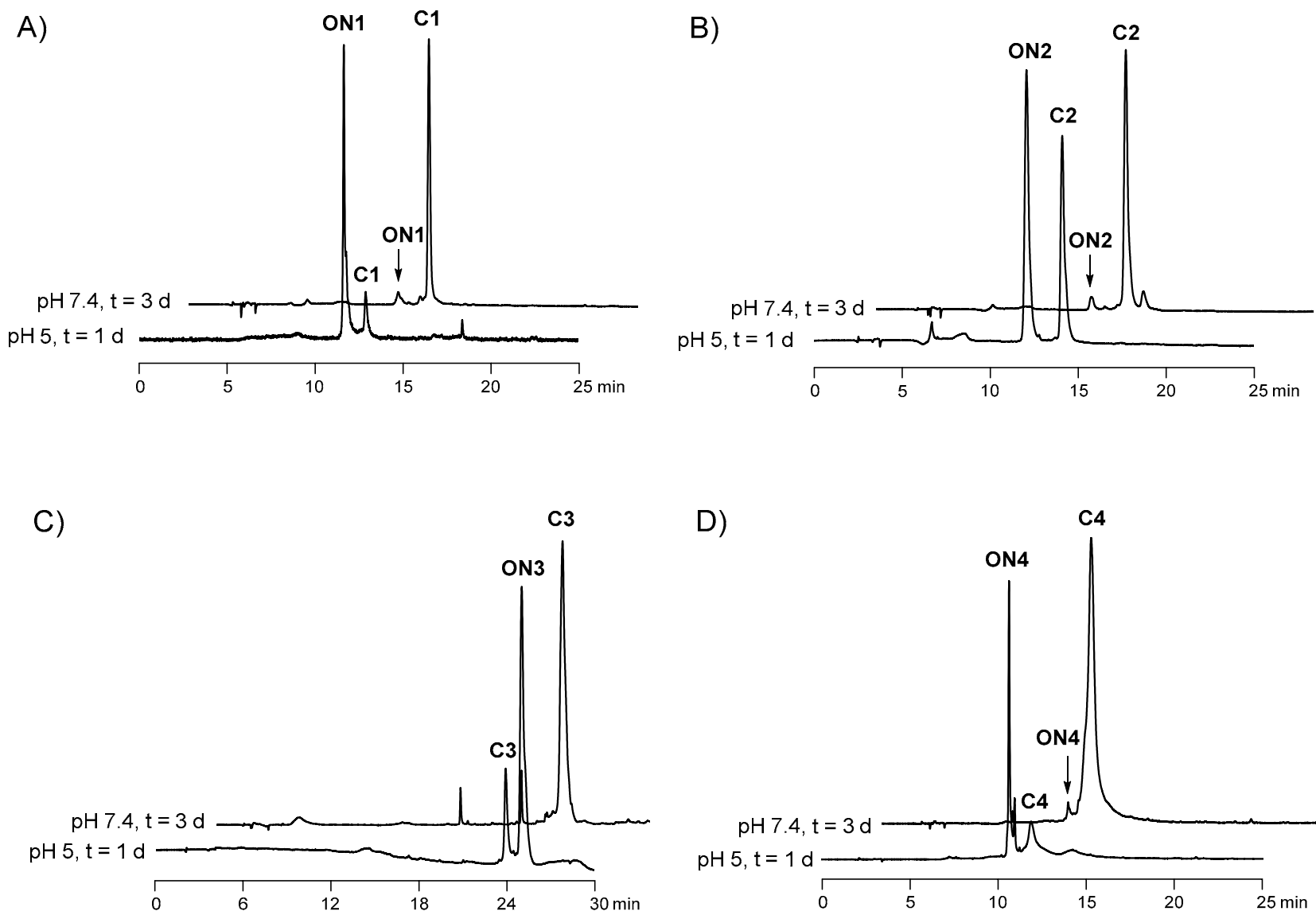

Figure 4. Selected RP HPLC $(\mathrm{C} 18,250 \times 4.6 \mathrm{~mm}, 5 \mu \mathrm{m})$ profiles of the conjugate hydrolysis reactions. A detection wavelength of $260 \mathrm{~nm}$ was employed (A) C1, a linear gradient of 0-60\% MeCN in 25 min over aq. TEAA buffer (pH 7); (B) C2, a linear gradient of $0-60 \% \mathrm{MeCN}$ in 25 min over aq. TEAA buffer (pH 7); (C) C3, a linear gradient of $0-50 \% \mathrm{MeCN}$ in 30 min over aq. hexylammonium acetate buffer (pH 7); (D) C4, 0-60\% MeCN in 25 min over aq. TEAA buffer (pH 7).

\section{Discussion}

The $N$-(methoxy)oxazolidine linker was found to be a reliable tool for conjugating $\mathrm{U}^{\mathrm{NOMe}}$-extended ONs to a variety of $\beta$-Ala-H-containing biomolecules. The rate of hydrolysis of the $N$-(methoxy)oxazolidine conjugates $\left(\mathrm{t}_{0.5}=4.4-10.2\right.$ at $\left.\mathrm{pH} 5\right)$ was in the range of the currently used acid-labile linkers that are applied in antibody-drug conjugates. For example, a phenylketone-derived hydrazine linker used in gemtuzumab ozogamicin (Mylotarg) [53] and inotuzumab ozogamicin (Besponsa) [54] has been determined to hydrolyze $97 \%$ in $24 \mathrm{~h}$ at $\mathrm{pH} 4.5$, which equals $\mathrm{t}_{0.5}=4.74 \mathrm{~h}$ (according to first-order kinetics), and only $6 \%$ at $\mathrm{pH} 7.4$ [53]. Obviously, the optimal release profiles of therapeutic ON conjugates may differ greatly from those of small-molecule drug conjugates. That said, the most central result here was that the release profile could be tuned by modifying the Gly- $\mathrm{H}$ aldehyde to a slightly less electron-deficient $\beta-\mathrm{Ala}-\mathrm{H}$ without losing the convenience of the conjugate synthesis. It may be assumed that the release rate may be further accelerated using similar simple modifications. Furthermore, the $\mathrm{N}$-(methoxy)oxazolidine conjugation was stable in concentrated ammonia. The option of removing the base-labile protecting groups post-conjugation may be useful in the synthesis of more complex conjugates or/and facilitating chromatographic issues. 


\section{Materials and Methods}

4.1. 4-\{3-(propynyloxy)-2,2-Bis [(propynyloxy)methyl]propoxy\}benzoic Acid (5)

Compound 4 (78 mg, $0.22 \mathrm{mmol}$ ) was dissolved in $\mathrm{MeCN}(1.5 \mathrm{~mL})$. A total of 1 equiv. of Jones reagent $\left(\mathrm{CrO}_{3} 22 \mathrm{mg}, 0.22 \mathrm{mmol} ; 22 \mu \mathrm{L} \mathrm{H}_{2} \mathrm{SO}_{4}\right.$; and $\mathrm{H}_{2} \mathrm{O}$ until the mixture is homogenous) was added to the mixture while stirring vigorously. The reaction was monitored by TLC ( $4 \% \mathrm{MeOH}$ in DCM), and Jones reagent was added twice in $30 \mathrm{~min}$ intervals $\left(1+1\right.$ equiv. of $\left.\mathrm{CrO}_{3}\right)$ until the oxidation was complete. The reaction was quenched by adding sat. aq. $\mathrm{NaHCO}_{3}(5 \mathrm{~mL})$ and the product was extracted twice with DCM $(2 \times 5 \mathrm{~mL})$. The organic phases were combined and washed twice with brine $(5 \mathrm{~mL})$. The organic phase was dried with $\mathrm{Na}_{2} \mathrm{SO}_{4}$, filtered, and evaporated to dryness to yield the product $(5,60 \mathrm{mg}, 73 \%)$ as a transparent glassy substance. ${ }^{1} \mathbf{H} \mathbf{N M R} \delta_{\mathrm{H}}(600 \mathrm{MHz}$, $\left.\mathrm{CDCl}_{3}\right): 8.07(2 \mathrm{H}, \mathrm{d}, J=8.4 \mathrm{~Hz}), 6.98(2 \mathrm{H}, \mathrm{d}, J=9.0 \mathrm{~Hz}), 4.16(6 \mathrm{H}, \mathrm{d}, J=2.4 \mathrm{~Hz}), 4.08(1 \mathrm{H}, \mathrm{s})$, $3.68(6 \mathrm{H}, \mathrm{s}), 2.42(3 \mathrm{H}, \mathrm{t}, J=2.4 \mathrm{~Hz}) .{ }^{13} \mathrm{C}$ NMR $\delta_{\mathrm{C}}(150 \mathrm{MHz}): 171.7,163.6,132.2,121.6,114.4$, 79.8, 74.3, 68.6, 66.9, 58.8, 44.8. HRMS-ESI (m/z) calc. for $\mathrm{C}_{21} \mathrm{H}_{23} \mathrm{O}_{6}\left[\mathrm{M}+\mathrm{H}^{+}\right]^{+}$: 371.1495; found: 371.1492 .

\subsection{N-(3,3-diethoxypropyl)-4-\{3-(propynyloxy)-2,2-bis [(propynyloxy)methyl]propoxy\}benzamide (6)}

BOP $(54 \mathrm{mg}, 0.11 \mathrm{mmol}$, predissolved in anhydrous DMF, $0.50 \mathrm{~mL}$ ) was added to a mixture of compound 5 ( $37 \mathrm{mg}, 0.10 \mathrm{mmol}), 3$-amino-1,1-diethoxypropane (18 $\mu \mathrm{L}$, $0.11 \mathrm{mmol})$, and DIPEA $(44 \mu \mathrm{L}, 0.25 \mathrm{mmol})$ in DMF $(0.50 \mathrm{~mL})$. The reaction mixture was stirred overnight in room temperature and then quenched with sat. aq. $\mathrm{NaHCO}_{3}(5 \mathrm{~mL})$. The product was extracted with EtOAc $(2 \times 5 \mathrm{~mL})$. The organic phase was washed with sat. aq. $\mathrm{NaHCO}_{3}(3 \mathrm{~mL})$ and brine $(3 \mathrm{~mL})$, dried with $\mathrm{Na}_{2} \mathrm{SO}_{4}$, filtered, and evaporated to dryness. The crude product was purified by silica gel chromatography $(6 \% \mathrm{MeOH}$ in DCM) to yield the product $(6,31 \mathrm{mg}, 60 \%)$ as a white foam. ${ }^{1} \mathbf{H}$ NMR $\delta_{\mathrm{H}}\left(600 \mathrm{MHz}, \mathrm{CDCl}_{3}\right) 7.72$ $(2 \mathrm{H}, \mathrm{d}, J=8.4 \mathrm{~Hz}), 6.94(2 \mathrm{H}, \mathrm{d}, J=9.0 \mathrm{~Hz}), 4.65(1 \mathrm{H}, \mathrm{t}, J=5.4 \mathrm{~Hz}), 4.15(6 \mathrm{H}, \mathrm{d}, J=2.4 \mathrm{~Hz})$, $4.04(1 \mathrm{H}, \mathrm{s}), 3.74(2 \mathrm{H}, \mathrm{m}), 3.67(6 \mathrm{H}, \mathrm{s}), 3.58(2 \mathrm{H}, \mathrm{m}), 3.55(2 \mathrm{H}, \mathrm{m}), 2.41(3 \mathrm{H}, \mathrm{t}, J=2.4 \mathrm{~Hz})$, $1.96(2 \mathrm{H}, \mathrm{m}), 1.26(6 \mathrm{H}, \mathrm{t}, J=7.2 \mathrm{~Hz}){ }^{13} \mathrm{C}$ NMR $\delta_{\mathrm{C}}(150 \mathrm{MHz}): 166.6,161.6,128.4,127.1$, 114.4, 103.2, 79.8, 74.3, 68.7, 66.8, 62.2, 58.8, 44.8, 35.9, 32.8, 15.4. HRMS-ESI (m/z) calc. for $\mathrm{C}_{28} \mathrm{H}_{37} \mathrm{NNaO}_{7}\left[\mathrm{M}+\mathrm{Na}^{+}\right]^{+}$: 522.2468; found 522.2460.

\subsection{Diethoxy Acetal-Protected Trivalent GalNAc Cluster (7)}

(3-azidopropyl) 2-acetamido-3,4,6-tri-O-acetyl-2-deoxy- $\beta$-D-galactopyranoside ( $88 \mathrm{mg}$, $0.20 \mathrm{mmol})$ [55] and compound $6(15 \mathrm{mg}, 0.041 \mathrm{mmol})$ were dissolved in a mixture of $\mathrm{DMF} /$ dioxane $/ \mathrm{H}_{2} \mathrm{O}(3: 3: 1, v / v / v, 0.60 \mathrm{~mL})$. A crystal of $\mathrm{CuI}$ was added and the mixture was stirred overnight on oil bath $\left(40^{\circ} \mathrm{C}\right)$. The reaction was quenched by adding aq. EDTA $(0.1 \mathrm{M}, 4 \mathrm{~mL})$. The product was extracted with DCM $(12 \mathrm{~mL})$. The organic phase was washed with aq. EDTA $(0.1 \mathrm{M}, 4 \mathrm{~mL}), \mathrm{H}_{2} \mathrm{O}(4 \mathrm{~mL})$, and brine $(4 \mathrm{~mL})$, then dried with $\mathrm{Na}_{2} \mathrm{SO}_{4}$, filtered, and evaporated to dryness. The crude product was purified by silica gel chromatography $(6-10 \% \mathrm{MeOH}$ in DCM) to yield the product $(7,32 \mathrm{mg}, 43 \%)$ as a white foam. ${ }^{1} \mathrm{H}-\mathrm{NMR} \delta_{\mathrm{H}}\left(600 \mathrm{MHz}, \mathrm{CDCl}_{3}\right): 7.65(2 \mathrm{H}, \mathrm{d}, J=8.4 \mathrm{~Hz}), 7.57(2 \mathrm{H}, \mathrm{s}), 6.79$ $(2 \mathrm{H}, \mathrm{d}, J=9.0 \mathrm{~Hz}), 5.28(3 \mathrm{H}, \mathrm{d}, J=3.0 \mathrm{~Hz}), 5.02(3 \mathrm{H}, \mathrm{dd}, J=11.0 \mathrm{~Hz} \& 3.0 \mathrm{~Hz}), 4.50(6 \mathrm{H}, \mathrm{s})$, $4.48-4.36(7 \mathrm{H}, \mathrm{m}), 4.29(3 \mathrm{H}, \mathrm{m}), 4.11(3 \mathrm{H}, \mathrm{dd}, J=9.9 \mathrm{~Hz} \& 8.4 \mathrm{~Hz}), 4.07(6 \mathrm{H}, \mathrm{m}), 3.88(2 \mathrm{H}, \mathrm{s})$, $3.84(6 \mathrm{H}, \mathrm{m}), 3.62(4 \mathrm{H}, \mathrm{q}, J=7.2 \mathrm{~Hz}), 3.51(6 \mathrm{H}, \mathrm{s}), 3.44(2 \mathrm{H}, \mathrm{t}, J=5.4 \mathrm{~Hz}), 3.28(3 \mathrm{H}, \mathrm{m}), 2.10$ $(12 \mathrm{H}, \mathrm{m}), 1.98(12 \mathrm{H}, \mathrm{m}), 1.95(9 \mathrm{H}, \mathrm{m}), 1.90(11 \mathrm{H}, \mathrm{m}), 1.16(6 \mathrm{H}, \mathrm{t}, J=7.2 \mathrm{~Hz}) .{ }^{13} \mathrm{C}-\mathrm{NMR} \delta_{\mathrm{C}}$ (150 MHz): 160.7, 170.6, 167.3, 161.5, 144.8, 128.6, 123.4, 123.4, 114.2, 103.9, 101.5, 70.5, 68.5, $66.6,65.4,64.4,61.4,57.9,50.3,46.7,45.0,35.7,31.8,30.1,22.9,20.5,18.0$. MS-ESI $(\mathrm{m} / \mathrm{z})$ calc. for $\mathrm{C}_{77} \mathrm{H}_{116} \mathrm{~N}_{13} \mathrm{NO}_{34}[\mathrm{M}+\mathrm{H}]^{+}$: 1790.8; found 1790.8.

\subsection{Trivalent GalNAc Cluster (8)}

Compound 7 was dissolved in aqueous $0.01 \%$ TFA and placed in $55^{\circ} \mathrm{C}$ oven. After $20 \mathrm{~min}$, HRMS (ESI-TOF) indicated the complete hydrolysis of the acetal to aldehyde. 
The reaction mixture was evaporated to dryness. The obtained 8 was used as such in the conjugation. MS-ESI $(m / z)$ calc. for $\mathrm{C}_{75} \mathrm{H}_{105} \mathrm{~N}_{13} \mathrm{NaO}_{33}[\mathrm{M}+\mathrm{Na}]^{+}$: 1738.7; found 1738.6.

\subsection{Synthesis of Conjugates C1-C4 Using N-(methoxy)oxazolidine Ligation}

ON1-ON4 (100 nmol) and the conjugate molecules (P1, P2, PNA1 and 8, 2-8 equiv, cf. Table 3) in a mixture $2 \mathrm{~mol} \mathrm{~L}^{-1} \mathrm{LiCl}$ in DMSO/AcOH $(20 \mu \mathrm{L}, 3: 1, v / v)$ were incubated for one hour at $55^{\circ} \mathrm{C}$. The reaction mixtures were quenched by adding $\mathrm{NaOH}(0.12 \mathrm{M})$ to $\mathrm{H}_{2} \mathrm{O} / \mathrm{MeCN}(1: 1, v / v)$ and subjected them to RP HPLC (Figure 4). The product fractions were collected and lyophilized. Conjugate $\mathbf{C} 3^{\mathrm{Ac}}$ was dissolved in concentrated aq. ammonia. The mixture was incubated for $3 \mathrm{~h}$ in room temperature and evaporated to dryness to yield C3. The yields of the isolated conjugates (Table 3) were determined from the UV absorbance at $260 \mathrm{~nm}$ using the molar absorptivity of the corresponding nucleobases. The authenticity of the products was verified by MS (ESI-TOF).

Supplementary Materials: The following are available online: small-molecule syntheses ( $N$-Bz-3amino-1,1-diethoxypropane, $N$-Bz- $\beta$-Ala-H, N-Fmoc-3-amino-1,1-diethoxypropane); NMR ( ${ }^{1} \mathrm{H}$ and ${ }^{13} \mathrm{C}$ ) spectra of compounds 5, 6, and 7; synthesis of ON1, ON2, ON3, ON4, and their mass spectra and RP HPLC chromatograms after purification; synthesis of oxazolidine $\beta$-Ala-H solid support 3; synthesis of P1, P2, and PNA1 and their mass spectra and RP HPLC chromatograms after purification; mass spectra for conjugates $\mathbf{C} 1, \mathbf{C} 2, \mathbf{C}^{\mathrm{Ac}}, \mathbf{C} 3$, and $\mathbf{C 4}$, small molecule model: studying the reversible $N$-(methoxy)oxazolidine formation between $\mathbf{1}$ and $N$-Bz- $\beta$-Ala-H including representative RP HPLC profile, kinetic profiles, and NMR $\left({ }^{1} \mathrm{H}\right.$ and $\left.{ }^{13} \mathrm{C}\right)$ characterization of the ligation products; determining hydrolysis rates of the conjugates $\mathbf{C 1}, \mathbf{C} 2, \mathbf{C} 3$, and $\mathbf{C} 4$ including kinetic profiles. References [56-58] are cited in the supplementary materials.

Author Contributions: Conceptualization, P.V.; methodology, A.A. and P.V.; investigation, A.A., A.Ä., H.K.; writing—original draft preparation, A.A., P.V., A.Ä., H.K.; writing—review and editing, A.A., and P.V.; visualization, A.A. and P.V.; supervision, P.V.; funding acquisition, P.V. All authors have read and agreed to the published version of the manuscript.

Funding: The financial support from the Academy of Finland (308931) and Business Finland $(448 / 31 / 2018)$ is acknowledged.

Institutional Review Board Statement: Not applicable.

Informed Consent Statement: Not applicable.

Data Availability Statement: The primary data presented in this study are available on request from the corresponding author.

Conflicts of Interest: The authors declare no conflict of interest.

\section{References}

1. Ngamcherdtrakul, W.; Castro, D.J.; Gu, S.; Morry, J.; Reda, M.; Gray, J.W.; Yantasee, W. Current development of targeted oligonucleotide-based cancer therapies: Perspective on HER2-positive breast cancer treatment. Cancer Treat. Rev. 2016, 45, 19-29. [CrossRef] [PubMed]

2. Martinovich, K.M.; Shaw, N.C.; Kicic, A.; Schultz, A.; Fletcher, S.; Wilton, S.D.; Stick, S.M. The potential of antisense oligonucleotide therapies for inherited childhood lung diseases. Mol. Cell. Pediatr. 2018, 5, 3. [CrossRef] [PubMed]

3. Rinaldi, C.; Wood, M.J.A. Antisense oligonucleotides: The next frontier for treatment of neurological disorders. Nat. Rev. Neurol. 2018, 14, 9-21. [CrossRef] [PubMed]

4. Di Fusco, D.; Dinallo, V.; Marafini, I.; Figliuzzi, M.M.; Romano, B.; Monteleone, G. Antisense Oligonucleotide: Basic Concepts and Therapeutic Application in Inflammatory Bowel Disease. Front. Pharmacol. 2019, 10, 305. [CrossRef]

5. Le, B.T.; Raguraman, P.; Kosbar, T.R.; Fletcher, S.; Wilton, S.D.; Veedu, R.N. Antisense Oligonucleotides Targeting Angiogenic Factors as Potential Cancer Therapeutics. Mol. Ther. Nucleic Acids 2019, 14, 142-157. [CrossRef]

6. Krichevsky, A.M.; Uhlmann, E.J. Oligonucleotide Therapeutics as a New Class of Drugs for Malignant Brain Tumors: Targeting mRNAs, Regulatory RNAs, Mutations, Combinations, and Beyond. Neurotherapeutics 2019, 16, 319-347. [CrossRef]

7. Takakura, K.; Kawamura, A.; Torisu, Y.; Koido, S.; Yahagi, N.; Saruta, M. The Clinical Potential of Oligonucleotide Therapeutics against Pancreatic Cancer. Int. J. Mol. Sci. 2019, 20, 3331. [CrossRef]

8. Roberts, T.C.; Langer, R.; Wood, M.J.A. Advances in oligonucleotide drug delivery. Nat. Rev. Drug. Discov. 2020, 19, 673-694. [CrossRef] 
9. Alkhouri, N.; Reddy, G.K.; Lawitz, E. Oligonucleotide-Based Therapeutics: An Emerging Strategy for the Treatment of Chronic Liver Diseases. Hepatology 2020. [CrossRef]

10. Dirin, M.; Winkler, J. Influence of diverse chemical modifications on the ADME characteristics and toxicology of antisense oligonucleotides. Expert Opin. Biol. Ther. 2013, 13, 875-888. [CrossRef]

11. Geary, R.S.; Norris, D.; Yu, R.; Bennett, C.F. Pharmacokinetics, biodistribution and cell uptake of antisense oligonucleotides. Adv. Drug Deliv. Rev. 2015, 87, 46-51. [CrossRef] [PubMed]

12. Juliano, R.L. The delivery of therapeutic oligonucleotides. Nucleic Acids Res. 2016, 44, 6518-6548. [CrossRef] [PubMed]

13. Song, E.; Zhu, P.; Lee, S.; Chowdhury, D.; Kussman, S.; Dykxhoorn, D.M.; Feng, Y.; Palliser, D.; Weiner, D.B.; Shankar, P.; et al. Antibody mediated in vivo delivery of small interfering RNAs via cell-surface receptors. Nat. Biotechnol. 2005, $23,709-717$. [CrossRef] [PubMed]

14. Uckun, F.M.; Qazi, S.; Dibirdik, I.; Myers, D.E. Rational design of an immunoconjugate for selective knock-down of leukemiaspecific E2A-PBX1 fusion gene expression in human Pre-B leukemia. Integr. Biol. 2013, 5, 122-132. [CrossRef]

15. Cuellar, T.L.; Barnes, D.; Nelson, C.; Tanguay, J.; Yu, S.; Wen, X.; Scales, S.J.; Gesch, J.; Davis, D.; van Brabant Smith, A.; et al. Systematic evaluation of antibody-mediated siRNA delivery using an industrial platform of THIOMAB-siRNA conjugates. Nucleic Acids Res. 2015, 43, 1189-1203. [CrossRef]

16. McNamara, J.O.; Andrechek, E.R.; Wang, Y.; Viles, K.D.; Rempel, R.E.; Gilboa, E.; Sullenger, B.A.; Giangrande, P.H. Cell typespecific delivery of siRNAs with aptamer-siRNA chimeras. Nat. Biotechnol. 2006, 24, 1005-1015. [CrossRef]

17. Zhou, J.; Rossi, J. Cell-Type-Specific Aptamer and Aptamer-Small Interfering RNA Conjugates for Targeted Human Immunodeficiency Virus Type 1 Therapy. J. Investig. Med. 2014, 62, 914. [CrossRef]

18. Gilleron, J.; Querbes, W.; Zeigerer, A.; Borodovsky, A.; Marsico, G.; Schubert, U.; Manygoats, K.; Seifert, S.; Andree, C.; Stöter, M.; et al. Image-based analysis of lipid nanoparticle-mediated siRNA delivery, intracellular trafficking and endosomal escape. Nat. Biotechnol. 2013, 31, 638-646. [CrossRef]

19. Yerneni, S.S.; Lathwal, S.; Shrestha, P.; Shirwan, H.; Matyjaszewski, K.; Weiss, L.; Yolcu, E.S.; Campbell, P.G.; Das, S.R. Rapid OnDemand Extracellular Vesicle Augmentation with Versatile Oligonucleotide Tethers. ACS Nano 2019, 13, 10555. [CrossRef]

20. Zatsepin, T.S.; Oretskaya, T.S. Synthesis and applications of oligonucleotide-carbohydrate conjugates. Chem. Biodivers 2004, 1, 1401-1417. [CrossRef]

21. Nair, J.K.; Willoughby, J.L.; Chan, A.; Charisse, K.; Alam, M.R.; Wang, Q.; Hoekstra, M.; Kandasamy, P.; Kel'in, A.V.; Milstein, S.; et al. Multivalent N-acetylgalactosamine-conjugated siRNA localizes in hepatocytes and elicits robust RNAimediated gene silencing. J. Am. Chem. Soc. 2014, 136, 16958-16961. [CrossRef]

22. Springer, A.D.; Dowdy, S.F. GalNAc-siRNA Conjugates: Leading the Way for Delivery of RNAi Therapeutics. Nucleic Acid Ther. 2018, 28, 109-118. [CrossRef] [PubMed]

23. Godeau, G.; Staedel, C.; Barthélémy, P. Lipid-Conjugated Oligonucleotides via "Click Chemistry" Efficiently Inhibit Hepatitis C Virus Translation. J. Med. Chem. 2008, 51, 4374-4376. [CrossRef] [PubMed]

24. Chernikov, I.V.; Gladkikh, D.V.; Meschaninova, M.I.; Ven'yaminova, A.G.; Zenkova, M.A.; Vlassov, V.V.; Chernolovskaya, E.L. Cholesterol-Containing Nuclease-Resistant siRNA Accumulates in Tumors in a Carrier-free Mode and Silences MDR1 Gene. Mol. Ther. Nucleic Acids 2017, 6, 209-220. [CrossRef]

25. Nishina, K.; Unno, T.; Uno, Y.; Kubodera, T.; Kanouchi, T.; Mizusawa, H.; Yokota, T. Efficient in vivo delivery of siRNA to the liver by conjugation of alpha-tocopherol. Mol. Ther. 2008, 16, 734-740. [CrossRef] [PubMed]

26. Nakagawa, O.; Ming, X.; Huang, L.; Juliano, R.L. Targeted Intracellular Delivery of Antisense Oligonucleotides via Conjugation with Small-Molecule Ligands. J. Am. Chem. Soc. 2010, 132, 8848-8849. [CrossRef] [PubMed]

27. Dohmen, C.; Fröhlich, T.; Lächelt, U.; Röhl, I.; Vornlocher, H.; Hadwiger, P.; Wagner, E. Defined Folate-PEG-siRNA Conjugates for Receptor-specific Gene Silencing. Mol. Ther. Nucleic Acids 2012, 1, e7. [CrossRef]

28. Juliano, R.L.; Ming, X.; Nakagawa, O. Cellular Uptake and Intracellular Trafficking of Antisense and siRNA Oligonucleotides. Bioconjugate Chem. 2012, 23, 147-157.

29. Juliano, R.; Alam, M.R.; Dixit, V.; Kang, H. Mechanisms and strategies for effective delivery of antisense and siRNA oligonucleotides. Nucleic Acids Res. 2008, 36, 4158-4171. [CrossRef]

30. Lönn, P.; Dowdy, S.F. Cationic PTD/CPP-mediated macromolecular delivery: Charging into the cell. Expert Opin. Drug Deliv. 2015, 12, 1627-1636. [CrossRef] [PubMed]

31. Gait, M.J.; Arzumanov, A.A.; McClorey, G.; Godfrey, C.; Betts, C.; Hammond, S.; Wood, M.J.A. Cell-Penetrating Peptide Conjugates of Steric Blocking Oligonucleotides as Therapeutics for Neuromuscular Diseases from a Historical Perspective to Current Prospects of Treatment. Nucleic Acid Ther. 2019, 29, 1-12. [CrossRef] [PubMed]

32. Nakajima, M.; Kasuya, T.; Yokota, S.; Onishi, R.; Ikehara, T.; Kugimiya, A.; Watanabe, A. Gene Silencing Activity and Hepatic Accumulation of Antisense Oligonucleotides Bearing Cholesterol-Conjugated Thiono Triester at the Gap Region. Nucleic Acid Ther. 2017, 27, 232-237. [CrossRef] [PubMed]

33. Yang, J.; Chen, C.; Tang, X. Cholesterol-Modified Caged siRNAs for Photoregulating Exogenous and Endogenous Gene Expression. Bioconjugate Chem. 2018, 29, 1010-1015. [CrossRef]

34. Bargh, J.D.; Isidro-Llobet, A.; Parker, J.S.; Spring, D.R. Cleavable linkers in antibody-drug conjugates. Chem. Soc. Rev. 2019, 48, 4361-4374. [CrossRef] [PubMed] 
35. Zatsepin, T.S.; Stetsenko, D.A.; Arzumanov, A.A.; Romanova, E.A.; Gait, M.J.; Oretskaya, T.S. Synthesis of Peptide-Oligonucleotide Conjugates with Single and Multiple Peptides Attached to 2'-Aldehydes through Thiazolidine, Oxime, and Hydrazine Linkages. Bioconjugate Chem. 2002, 13, 822-830. [CrossRef] [PubMed]

36. Ollivier, N.; Olivier, C.; Gouyette, C.; Huynh-Dinh, T.; Gras-Masse, H.; Melnyk, O. Synthesis of oligonucleotide-peptide conjugates using hydrazone chemical ligation. Tetrahedron Lett. 2002, 43, 997-999. [CrossRef]

37. Aho, A.; Sulkanen, M.; Korhonen, H.; Virta, P. Conjugation of Oligonucleotides to Peptide Aldehydes via a pH-Responsive N-Methoxyoxazolidine Linker. Org. Lett. 2020, 22, 6714-6718. [CrossRef] [PubMed]

38. Luna Velez, M.V.; Verhaegh, G.W.; Smit, F.; Sedelaar, J.P.M.; Schalken, J.A. Suppression of prostate tumor cell survival by antisense oligonucleotide-mediated inhibition of AR-V7 mRNA synthesis. Oncogene 2019, 38, 3696-3709. [CrossRef]

39. Li, Q. Nusinersen as a Therapeutic Agent for Spinal Muscular Atrophy. Yonsei Med. J. 2020, 61, 273-283. [CrossRef]

40. Yu, X.X.; Murray, S.F.; Pandey, S.K.; Booten, S.L.; Bao, D.; Song, X.Z.; Kelly, S.; Chen, S.; McKay, R.; Monia, B.P.; et al. Antisense oligonucleotide reduction of DGAT2 expression improves hepatic steatosis and hyperlipidemia in obese mice. Hepatology 2005, 42, 362-371. [CrossRef]

41. Choi, C.S.; Savage, D.B.; Kulkarni, A.; Yu, X.X.; Liu, Z.X.; Morino, K.; Kim, S.; Distefano, A.; Samuel, V.T.; Neschen, S.; et al. Suppression of diacylglycerol acyltransferase-2 (DGAT2), but not DGAT1, with antisense oligonucleotides reverses diet-induced hepatic steatosis and insulin resistance. J. Biol. Chem. 2007, 282, 22678-22688. [CrossRef] [PubMed]

42. Macdonald, J.; Houghton, P.; Xiang, D.; Duan, W.; Shigdar, S. Truncation and Mutation of a Transferrin Receptor Aptamer Enhances Binding Affinity. Nucleic Acid Ther. 2016, 26, 348-354. [CrossRef] [PubMed]

43. Zakeri, B.; Fierer, J.O.; Celik, E.; Chittock, E.C.; Schwarz-Linek, U.; Moy, V.T.; Howarth, M. Peptide tag forming a rapid covalent bond to a protein, through engineering a bacterial adhesin. Proc. Natl. Acad. Sci. USA 2012, 109, 690. [CrossRef]

44. Arranz-Gibert, P.; Ciudad, S.; Seco, J.; García, J.; Giralt, E.; Teixidó, M. Immunosilencing peptides by stereochemical inversion and sequence reversal: Retro-D-peptides. Sci. Rep. 2018, 8, 6446. [CrossRef]

45. Lee, J.H.; Engler, J.A.; Collawn, J.F.; Moore, B.A. Receptor mediated uptake of peptides that bind the human transferrin receptor. Eur. J. Biochem. 2001, 268, 2004-2012. [CrossRef] [PubMed]

46. Prades, R.; Guerrero, S.; Araya, E.; Molina, C.; Salas, E.; Zurita, E.; Selva, J.; Egea, G.; López-Iglesias, C.; Teixidó, M.; et al. Delivery of gold nanoparticles to the brain by conjugation with a peptide that recognizes the transferrin receptor. Biomaterials 2012, 33, 7194-7205. [CrossRef] [PubMed]

47. Rembach, A.; Turner, B.J.; Bruce, S.; Cheah, I.K.; Scott, R.L.; Lopes, E.C.; Zagami, C.J.; Beart, P.M.; Cheung, N.S.; Langford, S.J.; et al. Antisense peptide nucleic acid targeting GluR3 delays disease onset and progression in the SOD1 G93A mouse model of familial ALS. J. Neurosci. Res. 2004, 77, 573-582. [CrossRef] [PubMed]

48. Ede, N.J.; Bray, A.M. A simple linker for the attachment of aldehydes to the solid phase. Application to solid phase synthesis by the multipin ${ }^{\mathrm{TM}}$ method. Tetrahedron Lett. 1997, 38, 7119-7122. [CrossRef]

49. Ede, N.J.; Eagle, S.N.; Wickham, G.; Bray, A.M.; Warne, B.; Shoemaker, K.; Rosenberg, S. Solid phase synthesis of peptide aldehyde protease inhibitors. Probing the proteolytic sites of hepatitis C virus polyprotein. J. Peptide Sci. 2000, 6, 11-18. [CrossRef]

50. Kushnarova-Vakal, A.; Äärelä, A.; Huovinen, T.; Virta, P.; Lamminmäki, U. Site-Specific Linking of an Oligonucleotide to Mono- and Bivalent Recombinant Antibodies with SpyCatcher-SpyTag System for Immuno-PCR. ACS omega 2020, 5, 24927-24934. [CrossRef]

51. Mäkilä, J.; Jadhav, S.; Kiviniemi, A.; Käkelä, M.; Liljenbäck, H.; Poijärvi-Virta, P.; Laitala-Leinonen, T.; Lönnberg, H.; Roivainen, A.; Virta, P. Synthesis of multi-galactose-conjugated 2'-O-methyl oligoribonucleotides and their in vivo imaging with positron emission tomography. Bioorg. Med. Chem. 2014, 22, 6806-6813. [CrossRef] [PubMed]

52. Karskela, M.; Helkearo, M.; Virta, P.; Lönnberg, H. Synthesis of Oligonucleotide Glycoconjugates Using Sequential Click and Oximation Ligations. Bioconjugate Chem. 2010, 21, 748-755. [CrossRef] [PubMed]

53. Hamann, P.R.; Hinman, L.M.; Hollander, I.; Beyer, C.F.; Lindh, D.; Holcomb, R.; Hallett, W.; Tsou, H.; Upeslacis, J.; Shochat, D.; et al. Gemtuzumab Ozogamicin, A Potent and Selective Anti-CD33 Antibody-Calicheamicin Conjugate for Treatment of Acute Myeloid Leukemia. Bioconjugate Chem. 2002, 13, 47-58. [CrossRef] [PubMed]

54. DiJoseph, J.F.; Armellino, D.C.; Boghaert, E.R.; Khandke, K.; Dougher, M.M.; Sridharan, L.; Kunz, A.; Hamann, P.R.; Gorovits, B.; Udata, C.; et al. Antibody-targeted chemotherapy with CMC-544: A CD22-targeted immunoconjugate of calicheamicin for the treatment of B-lymphoid malignancies. Blood 2004, 103, 1807-1814. [CrossRef] [PubMed]

55. Szekely, T.; Roy, O.; Dériaud, E.; Job, A.; Lo-Man, R.; Leclerc, C. Design, Synthesis, and Immunological Evaluation of a Multicomponent Construct Based on a Glycotripeptoid Core Comprising B and T Cell Epitopes and a Toll-like Receptor 7 Agonist That Elicits Potent Immune Responses. J. Med. Chem. 2018, 61, 9568-9582. [CrossRef]

56. Häring, A.P.; Biallas, P.; Kirsch, S.F. An Unconventional Reaction of 2,2-Diazido Acylacetates with Amines. Eur. J. Org. Chem. 2017, 2017, 1526-1539. [CrossRef]

57. Laitar, D.S.; Kramer, J.W.; Whiting, B.T.; Lobkovsky, E.B.; Coates, G.W. $\beta$-Amidoaldehydes via oxazoline hydroformylation. Chem. Commun. 2009, 5704-5706. [CrossRef]

58. Leyerer, K.; Koppermann, S.; Ducho, C. Solid Phase-Supported Synthesis of Muraymycin Analogues. Eur. J. Org. Chem. 2019, 2019, 7420-7431. [CrossRef] 